Open Access

\title{
Critical role of actin-associated proteins in smooth muscle contraction, cell proliferation, airway hyperresponsiveness and airway remodeling
}

Dale D. Tang

\begin{abstract}
Asthma is characterized by airway hyperresponsiveness and airway remodeling, which are largely attributed to increased airway smooth muscle contractility and cell proliferation. It is known that both chemical and mechanical stimulation regulates smooth muscle contraction. Recent studies suggest that contractile activation and mechanical stretch induce actin cytoskeletal remodeling in smooth muscle. However, the mechanisms that control actin cytoskeletal reorganization are not completely elucidated. This review summarizes our current understanding regarding how actin-associated proteins may regulate remodeling of the actin cytoskeleton in airway smooth muscle. In particular, there is accumulating evidence to suggest that Abelson tyrosine kinase (Abl) plays a critical role in regulating airway smooth muscle contraction and cell proliferation in vitro, and airway hyperresponsiveness and remodeling in vivo. These studies indicate that Abl may be a novel target for the development of new therapy to treat asthma.
\end{abstract}

\section{Introduction}

Airway smooth muscle cell contraction and proliferation contribute to the pathogenesis of airway hyperresponsiveness (AHR) and airway remodeling [1-8], cardinal features of asthma that affect nearly 25 million people in the United Sates and 250 million people worldwide (www.cdc.gov and www.who.int). However, the cellular and molecular mechanisms that regulate smooth muscle cell contraction and proliferation are not fully understood. Understanding these cellular processes is fundamental to our knowledge regarding smooth muscle biology and the pathogenesis of asthma.

Upon external stimulation, myosin light chain undergoes phosphorylation at Ser-19, which activates myosin ATPase and initiates sliding of contractile filaments and smooth muscle contraction $[9,10]$. More importantly, there is a wealth of evidence to suggest that actin cytoskeletal remodeling is critical for smooth muscle contraction. A pool of actin monomers polymerizes onto existing actin

Correspondence: tangd@mail.amc.edu

Center for Cardiovascular Sciences, Albany Medical College, 47 New Scotland Avenue, MC-8, Albany, NY 12208, USA filaments in smooth muscle in response to contractile stimulation. Inhibition of the G-actin to F-actin transition by pharmacological tools and molecular approach attenuates smooth muscle contraction without affecting myosin light chain phosphorylation [11-14]. Actin filament polymerization may promote smooth muscle force development by enhancing the transmission of force between the contractile unit and the extracellular matrix [11-16]. Smooth muscle contraction is similar to "the moving of a car". Myosin may serve as an "engine" for smooth muscle contraction whereas the actin cytoskeleton may function as a "transmission system" in smooth muscle $[17,18]$.

During breathing, airway smooth muscle is constantly subjected to mechanical oscillation, which affects airway smooth muscle contractility. There is evidence that mechanical stretch induces fluidization and resolidification of smooth muscle cells, suggesting actin cytoskeletal remodeling (actin depolymerization and polymerization) in the cells upon transient stretch [19]. However, the mechanisms underlying the dynamic actin cytoskeleton are not well elucidated. 
The mitogen-activated protein kinase (MAPK) pathway plays an essential role in regulating various cellular functions including cell proliferation [20-22]. In response to stimulation with growth factors within minutes, MEK1/2 (MAPK kinase) gets phosphorylated by Raf-1 kinase $[22,23]$, which in turn phosphorylates and activates extracellular signal-regulated kinase1/2 (ERK1/2). Activated ERK1/2 phosphorylates several protein kinases, transcription factors, and other proteins to promote cell proliferation eventually [20-23]. Recent studies demonstrate a critical role of actin-regulatory proteins in the growth factor-associated signaling and proliferation in smooth muscle cells [20,21, 24].

This review will summarize our current understanding of physiological properties of the actin-associated proteins in smooth muscle reactivity and proliferation in vitro and their roles in the pathogenesis of AHR and airway remodeling in vivo. In particular, there is evidence to suggest that Abelson tyrosine kinase ( $\mathrm{Abl}, \mathrm{c}-\mathrm{Abl})$ plays a critical role in controlling airway smooth muscle contraction and cell proliferation in vitro, and AHR and airway remodeling in vivo. These studies indicate that $\mathrm{Abl}$ may be a novel target for the development of new therapy to treat asthma.

\section{Role of actin-associated proteins in smooth muscle contraction}

\section{Critical role of actin polymerization in smooth muscle} contraction

Actin filaments of smooth muscle cells attach to dense plaques containing integrins on the membrane, and connect with dense bodies in the cytoplasm. The majority of actin (thin) filaments localize around myosin (thick) filaments in a rosette array, forming the contractile machinery. This pool of actin filaments is referred to as "contractile actin". In addition, "cytoskeletal actin" does not structurally interact with myosin filaments, which plays a role in maintaining the structural integrity of smooth muscle cells. The structure of the actin cytoskeleton in smooth muscle cells has been described in detail elsewhere [14, 25, 26].

\section{Actin polymerization and depolymerization occur during the contraction-relaxation cycle of smooth muscle}

There is accumulating evidence to suggest that actin filament polymerization transpires in smooth muscle in response to contractile activation, and actin depolymerization occurs during the relaxation of smooth muscle. First, we and others have used an actin fractionation assay and calculated that in unstimulated airway smooth muscle cells/tissues, $70-80 \%$ of total actin exists in insoluble actin (F-actin) whereas $20-30 \%$ of total actin is found in soluble actin (G-actin). In response to contractile activation, $85-90 \%$ of total actin is F-actin in airway smooth muscle cells/tissues [11, 16-18, 27-30]. By using the fractionation assay, a number of research teams have found that contractile stimulation increases the amount of F-actin and/or decreases the G-actin level in arterial smooth muscle tissues [12, 13, 29-31]. Furthermore, the F-actin/G-actin ratios are reduced in smooth muscle during relaxation [31-33]. Second, several groups including our laboratory have also used fluorescent microscopy to evaluate F-actin and G-actin by reacting smooth muscle tissues/cells with phalloidin (for F-actin) and DNase I (for G-actin) conjugated with fluorescent labels [33-36]. Treatment of human airway smooth muscle cells with carbachol and endothelin-1 leads to the increase in the ratio of F-actin to G-actin as estimated by fluorescence microscopy, whereas treatment with smooth muscle relaxants (isoproteronol and forskolin) decreases the F-actin/G-actin ratios [33, 36, 37]. In other studies, stimulation with vasoconstrictors enhances the F-actin/Gactin ratios in vascular smooth muscle as evaluated by fluorescent microscopy [12, 34, 35]. Third, a decrease of the G-actin pool was observed in contractile airway smooth muscle tissues by using the DNase inhibition assay $[11,14]$. In addition, Barany et al. also documented a reduced G-actin content in contractile arterial smooth muscle by measuring the exchange rates of actin-bound nucleotide [11,38]. Taken together, these studies demonstrate that actin polymerization and depolymerization occur in various smooth muscle cell/tissue types during the contraction-relaxation cycle.

\section{Inhibition of actin polymerization attenuates smooth muscle contraction}

The inhibition of actin polymerization by pharmacological agents such as cytochalasin or latrunculin attenuates the contraction in a variety of smooth muscle tissues including airway smooth muscle [32, 35, 39-41]. Cytochalasin caps existing actin filaments at the barbed end, preventing F-actin elongation whereas latrunculin binds to G-actin and blocks the assembly of G-actin onto actin filaments [11, 14, 42, 43]. The short-term treatment of smooth muscle with these inhibitors does not impair the organization and ultrastructure of contractile filaments $[11,14]$. Furthermore, inhibition of actin polymerization by molecular approaches that interfere with actinregulatory proteins also attenuates smooth muscle contraction [16-18, 30, 35, 44-48]. More importantly, the suppression of actin polymerization inhibits force development in smooth muscle with little or no effects on myosin light chain phosphorylation, a cellular event that is essential for smooth muscle contraction [16-18, 30, 35, 44-48]. Therefore, these results suggest that actin filament polymerization and myosin activation are two parallel cellular processes that are fundamental for the regulation of smooth muscle contraction. 
How does actin polymerization affect the contraction in smooth muscle? First, the actin filaments of smooth muscle cells connect to the cytoplasmic domain of $\beta$ integrins via linker proteins such as vinculin, talin and $\alpha$-actinin whereas the extracellular portion of $\beta$ integrins engages with the extracellular matrix $[11,14,15,25,26,49,50]$. Thus, the actin-integrin-matrix connection provides the structural basis for the force transmission between the contractile unit and the extracellular matrix $[11,14,15,25$, $26,49-53]$. Nascent actin polymerization may occur at the cell cortex of smooth muscle [11, 14, 15, 25, 27, 28, 49, 54]. Cortical actin assembly may strengthen the linkage of actin filaments to integrins and enhance the transmission of contractile force $[11,14,15,25,30,35,44,53,55]$.

Second, actin filament assembly may participate in the "latch" formation of contractile filaments, supporting force maintenance under the condition of lower crossbridge phosphorylation $[13,14,56,57]$. Third, our recent studies suggest that actin polymerization promotes the recruitment of $\beta$-catenin to $\mathrm{N}$-cadherin (critical components of intercellular junctions), which may facilitate the cell-tocell force transmission and contraction [58].

\section{Regulation of actin dynamics in smooth muscle}

In the last decade, a wealth of information has been accumulated to elucidate how actin filament polymerization/ depolymeration is regulated in smooth muscle. Thus far, protein kinases, such as Abl, p21-activated kinase (PAK), focal adhesion kinase (FAK), integrin-linked kinase (ILK) and other kinases, have been reported to regulate actin polymerization in smooth muscle. Transmembrane integrins may be able to activate signaling pathways coordinating actin dynamics in smooth muscle. Rho, Cdc42, and Rac are the major members of Rho family of the small GTPases that mediates actin polymerization in smooth muscle. The actin-regulatory proteins are effectors in the signaling cascades to mediate actin dynamics. Some of the proteins are neuronal Wiskott-Aldrich syndrome Protein (N-WASP), the Arp2/3 complex, cortactin, glia maturation factor- $\gamma$ (GMF- $\gamma$ ), Abl interactor 1 (Abi1), profilin, cofilin, and heat shock proteins. Generally speaking, receptor activation and/or integrin ligation activates protein kinases and/or small GTPases, which subsequently regulate the functional status of the actin regulatory proteins and eventually actin filament assembly or structural reorganization. However, these protein interactions and signaling pathways are complex and may be cell-type and species dependent. The expression and role of actinassociated proteins in different cell types and species are summarized in Table 1.

\section{Role of Abl tyrosine kinase in smooth muscle}

$\mathrm{Abl}$ is a non-receptor protein tyrosine kinase that is ubiquitously expressed and has been implicated to function in a variety of cellular processes including the regulation of the actin cytoskeleton that mediates cell migration and adhesion [59-61]. There is evidence that Abl tyrosine kinase is necessary for airway smooth muscle contraction. Smooth muscle cell-specific knockout of Abl attenuates contractile responses of mouse tracheal rings to acetylcholine (ACh) [5]. Moreover, acute treatment with the Abl pharmacological inhibitors imatinib (Gleevec, STI-571) [5, 47, 62] and GNF-5 [63] significantly inhibits force development in mouse tracheal rings induced by ACh. Furthermore, treatment with imatinib or GNF-5 induces the relaxation of tracheal rings precontracted by ACh [5]. In addition, treatment with imatinib attenuates airway smooth muscle reactivity in vivo [64].

Abl has also been shown to regulate vascular smooth muscle contraction. Knockdown of Abl inhibits force development in arterial smooth muscle tissues during contractile activation [48]. Moreover, treatment with a cell permeable peptide or imatinib attenuates vascular smooth muscle contraction [47]. Interestingly, administration of the Abl inhibitor imatinib lessens the clinical symptoms of patients with pulmonary arterial hypertension [65, 66], suggesting a role for Abl in pulmonary arterial contraction.

How does Abl regulate force development in smooth muscle? To answer the question, the effects of $\mathrm{Abl}$ knockdown or inhibition on actin dynamics and myosin phosphorylation was evaluated. Knockdown of Abl attenuates actin polymerization in smooth muscle cells/tissues during contractile stimulation [14, 17, 48]. Inhibition of Abl activation by a cell permeable peptide also diminishes actin dynamics in smooth muscle stimulated by contractile agonists [47]. However, silencing or inhibition of Abl does not affect myosin light chain phosphorylation in smooth muscle $[47,48]$. These observations suggest that Abl regulate smooth muscle contraction by controlling actin polymerization, but not myosin activation during contractile stimulation [11, 12, 16-18, 35, 45].

Contractile stimulation induces phosphorylation of $\mathrm{Abl}$ tyrosine kinase at Tyr-412 in smooth muscle [47, 48]. Tyr412 is located at the activation loop of Abl kinase domain. When unstimulated, the activation loop of the Abl kinase domain folds into the active site, thereby preventing binding of both the substrate and ATP. Phosphorylation at Tyr-412 induces conformation changes; the activation loop no longer blocks the active site, which leads the increase in kinase activity $[14,47,48,60]$. Abl tyrosine phosphorylation is regulated by Src in smooth muscle cells/ tissues in response to contractile activation [15, 48, 67]. Similarly, Abl phosphorylation is also mediated by Src in fibroblasts [68] and cancer cells [69].

Abl regulates actin dynamics in smooth muscle by controlling several downstream effectors. Abi1 is an adapter 
Table 1 The expression and role of actin-associated proteins in different cell-types and species

\begin{tabular}{|c|c|c|c|c|}
\hline Name & Cell types & Species & Role & References \\
\hline Abi1 & ASMCs, VSMCs & Human & Adapter protein & {$[17]$} \\
\hline Abl & ASMCs, VSMCs & Human, rat, mouse & Tyrosine kinase & {$[5,17,47,48]$} \\
\hline Arp2/3 & ASMCs, VSMCs & Human, rat, canine & Promote actin branching & {$[17,48,54]$} \\
\hline CAS & ASMCs, VSMCs & Human, rat & Adapter protein & {$[17,48]$} \\
\hline Cdc42 & ASMCs & Canine & Small GTPase & {$[11,27,28]$} \\
\hline Cofilin & ASMCs & Canine & Actin regulator & {$[45]$} \\
\hline Cortactin & ASMCS & Human & Adapter protein & {$[18,125]$} \\
\hline Crkll & ASMCs & Canine & Adapter protein & [27] \\
\hline FAK & ASMCS & Canine & Tyrosine kinase & {$[87,88]$} \\
\hline GMF- $\gamma$ & ASMCs & Human & Promote actin debranching & [16] \\
\hline HDAC8 & ASMCS & Human, mouse & Histone deacetylase & [1111] \\
\hline HSP27 & ASMCs & Canine & Heat shock protein & [53] \\
\hline ILK & ASMCS & Canine & Adapter protein, kinase & {$[11,55]$} \\
\hline Integrin- $\beta_{1}$ & ASMCs & Human, canine & Link ECM to actin cytoskeleton & {$[52,55]$} \\
\hline $\mathrm{N}$-Cadherin & ASMCs & Human & Adherens junction protein & [58] \\
\hline N-WASP & ASMCs, VSMCs & Human, rat, canine & Promote actin nucleation & {$[17,48,55]$} \\
\hline p38MAPK & ASMCs & Canine & Serine/threonine kinase & [93] \\
\hline PAK1 & ASMCs & Canine, mouse, human & Serine/threonine kinase & {$[80,93,131]$} \\
\hline Parvin & ASMCs & Canine & Actin binding protein & {$[55]$} \\
\hline Paxillin & ASMCs & Canine & Adapter protein & {$[55,82,83]$} \\
\hline $\mathrm{PINCH}$ & ASMCs & Canine & ILK binding partner & {$[11,55]$} \\
\hline Profilin & ASMCs, VSMCs & Human, canine & Promote actin transport & {$[18,32]$} \\
\hline RhoA & ASMCS & Canine, human & Small GTPase & {$[30,104]$} \\
\hline Talin & ASMCS & Canine & Structural protein & {$[29,51]$} \\
\hline VASP & ASMCs & Canine & Phosphoprotein & [44] \\
\hline Vinculin & ASMCs & Canine & Structural protein & {$[29,51]$} \\
\hline a-Actinin & ASMCs & Canine & Cross linking protein & {$[52]$} \\
\hline$\beta$-Catenin & ASMCs & Human & Adherens junction protein & {$[58]$} \\
\hline
\end{tabular}

ASMCs airway smooth muscle cells, VASMCs vascular smooth muscle cells

protein that has been implicated in the regulation of actin dynamics in vitro [70], cell adhesion and migration $[71,72]$. In human airway smooth muscle cells/tissues, contractile stimulation induces an increase in the association of Abi1 with N-WASP (an actin nucleation activator) [17]. N-WASP is known to regulate the Arp2/3-mediated actin polymerization and branching $[55,73,74]$. Furthermore, contractile stimulation activates N-WASP in live smooth muscle cells as evidenced by changes in fluorescence resonance energy transfer efficiency of an N-WASP sensor [17]. Abi1 is necessary for N-WASP activation, actin polymerization and the contraction in smooth muscle. However, Abi1 does not affect myosin light chain phosphorylation [17]. More importantly, contractile activation induces the formation of a multiprotein complex including Abl, Crk-associated substrate (CAS) and Abi1. CAS is an adapter protein that participates in the regulation of smooth muscle tension development [15, 32, 39, 67]. Knockdown of Abl and CAS attenuates the activation of Abi1 during contractile activation. Collectively, the results indicate that Abl tyrosine kinase is able to regulate the formation of the CAS/Abi1/ N-WASP complex, which subsequently activates NWASP and actin polymerization [15, 17, 32, 39] (Fig. 1).

Cortactin is an actin-regulatory protein that is able to regulate actin filament assembly in in vitro studies as well as adhesion, migration, endocytosis of nonmuscle cells $[75,76]$. In human airway smooth muscle cells/tissues, cortactin controls actin polymerization and force development without affecting myosin activation [18]. Furthermore, contractile stimulation induces cortactin phosphorylation at Tyr-421 and the association of cortactin with profilin-1 (Pfn-1) that is able to transport actin monomers onto actin filaments [18, 32, 39]. The 


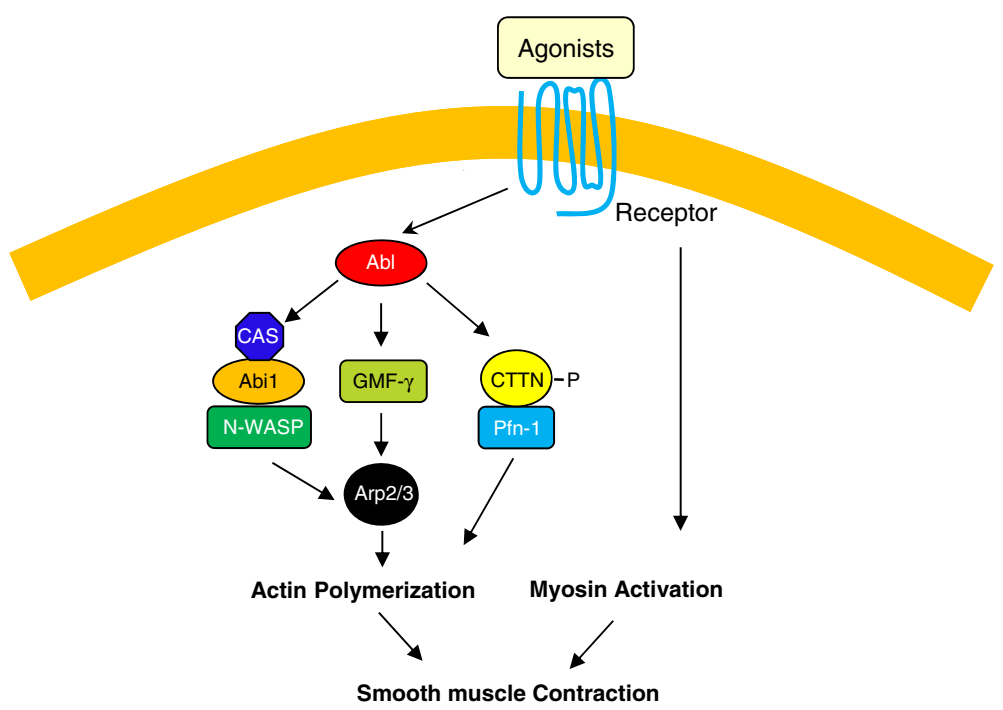

Fig. 1 Mechanisms of Abl-regulated actin polymerization. Stimulation with agonists such as acetylcholine may activate Abl tyrosine kinase, which regulates the formation of the multiprotein complex including Crk-associated substrate (CAS), the adapter protein Abi1 (Abl interactor 1) and N-WASP (neuronal Wiskott-Aldrich Syndrome Protein), which in turn activates N-WASP, actin polymerization and smooth muscle contraction. Activated Abl also catalyzes phosphorylation of GMF- $\gamma$ (glia maturation factor- - ) at Tyr-104, which induces the dissociation of GMF- $\gamma$ from Arp2/3, and promotes actin polymerization. Furthermore, contractile agonists promote the association of cortactin (CTTN) with profilin-1 (Pfn-1), which induces actin polymerization and smooth muscle contraction. The interaction of cortactin with Pfn-1 is regulated by cortactin phosphorylation and Abl tyrosine kinase

cortactin/Pfn-1 complex is also rapidly recruited to the membrane upon contractile activation. The disruption of the protein-protein interaction by a cell permeable peptide attenuates actin polymerization and smooth muscle contraction. More importantly, Abl has a critical role in regulating the agonist-induced cortactin phosphorylation and the interaction of cortactin with Pfn-1 [18]. These results suggest that cortactin phosphorylation and cortactin/Pfn-1 coupling play a pivotal role in regulating actin dynamics and smooth muscle contraction. Abl regulates the association of cortactin with Pfn-1 and actin polymerization by catalyzing cortactin phosphorylation (Fig. 1).

GMF- $\gamma$ is a member of actin-depolymerizing factor (ADF)/cofilin family that is widely expressed in eukaryotes and plays a central role in reorganizing the actin cytoskeleton by inducing actin network debranching $[77,78]$. GMF- $\gamma$ is able to inhibit actin nucleation in vitro [78]. Moreover, in vitro biochemical studies show that GMF- $\gamma$ may induce debranching of the actin filament networks [77, 78]. Knockdown of GMF- $\gamma$ enhances actin polymerization and the contraction in human airway smooth muscle cells/tissues with little or no effect on myosin phosphorylation [16]. Contractile activation induces GMF- $\gamma$ phosphorylation at Tyr-104 and dissociation of GMF- $\gamma$ from Arp2 of the Arp2/3 complex, which is regulated by Abl tyrosine kinase. Furthermore, expression of mutant Y104F GMF- $\gamma$ attenuates actin polymerization and contraction in smooth muscle [16]. Thus, Abl tyrosine kinase is able to phosphorylate GMF- $\gamma$ at Tyr-104, which inhibits the ability of GMF- $\gamma$ to induce actin network disassembly (Fig. 1).

\section{Role of the integrin-associated complex in actin polymerization}

Transmembrane integrins are localized in membraneassociated dense plaques (similar to focal adhesion sites of cultured cells) and connect the extracellular matrix with the actin cytoskeleton in smooth muscle $[11,14,15]$. In addition, a number of structural and signaling proteins are found in the integrin-associated structure (Fig. 2). During cell migration, the engagement of integrins with the extracellular matrix initiates the recruitment of actin-associated proteins to the membrane, which eventually promotes actin polymerization $[11,61,79]$. There is evidence to suggest that contractile stimulation induces the assembly of the multiprotein complex at the membrane, which is critical for the regulation of actin polymerization in smooth muscle [30, 35, 44, 45, 47, 55, 80, 81].

In canine tracheal smooth muscle, a stable protein complex containing ILK (a $\beta$-integrin binding scaffolding protein and protein kinase), PINCH (an ILK binding partners) and $\alpha$-parvin (an actin-binding protein) is recruited to integrin adhesion sites in response to contractile stimulation, where it interacts with $\beta$-integrins and forms a platform for the recruitment of other structural and signaling proteins that 


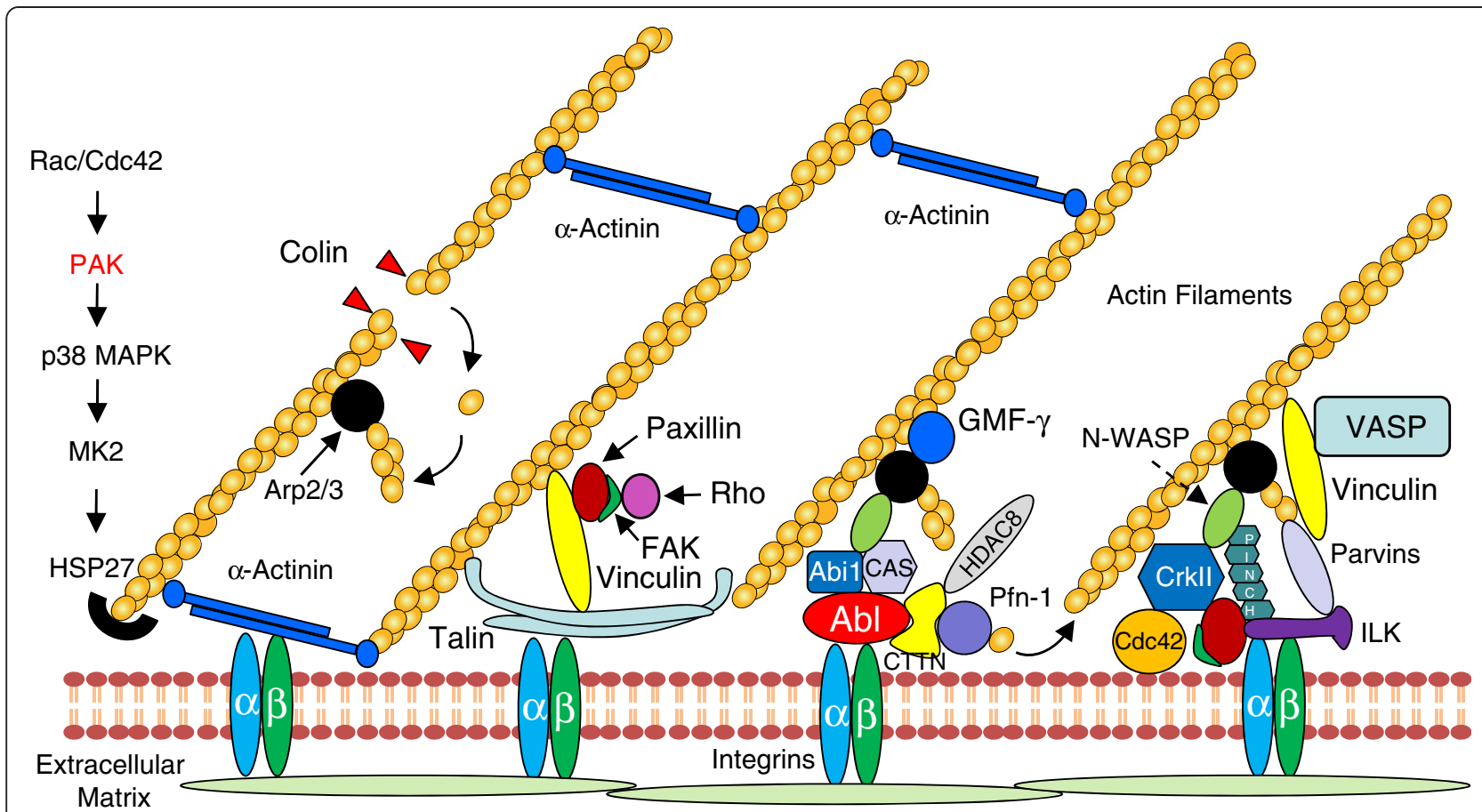

Fig. 2 Molecular interactions of scaffolding/signaling proteins at or near intergrin-associated junctions. Cytoplasmic tails of integrins connect with actin filaments via actin linker proteins such as talin, vinculin, paxillin and a-actinin. The extracellular domains of integrins interact with the extracellular matrix, forming the integrin-associated junctions. Signaling and scaffolding proteins are assembled at or near the integrin-associated junctions upon contractile activation, which facilitates actin polymerization and the mechanotransduction between the contractile unit and the extracellular matrix. Abi1, Abl interactor 1; Abl, Abelson tyrosine kinase; CAS, Crk-associated substrates; CTTN, cortactin; FAK, focal adhesion kinase; GMF- $\gamma$, glia maturation factor- $\gamma$; HDAC8, histone deacetylase 8; HSP, heat shock protein; ILK, integrin-linked kinase; MAPK, mitogen-activated protein kinase; MK2, MAP kinase-activated protein (MAPKAP) kinase 2; N-WASP, neuronal Wiskott-Aldrich Syndrome Protein; PAK, p21-activated kinase; Pfn-1, profilin-1; VASP, vasodilator stimulated phosphoprotein

are required for the processes of actin cytoskeletal remodeling and mechanotransduction $[11,55]$.

Paxillin, a scaffolding and signaling protein, is required for tracheal smooth muscle contraction $[82,83]$ and is also recruited to membrane adhesion sites in response to contractile stimulation, where it associates with the ILK-associated complex [55]. Paxillin has been shown to undergo tyrosine phosphorylation in response to contractile stimulation in many smooth muscle cell and tissue types [13, 84-86]. The tyrosine phosphorylation of paxillin at Tyr-31 and -118 promotes its interaction with the $\mathrm{SH} 2 / \mathrm{SH} 3$ adaptor protein CrkII, which binds to N-WASP and contributes to N-WASP and Arp $2 / 3$ activation [27]. Paxillin phosphorylation is mediated by FAK in smooth muscle $[87,88]$.

Integrin activation may also stimulate FAK and paxillin in smooth muscle; the tyrosine phosphorylation of FAK and paxillin is mechanosensitive (integrin is a known mechanosensor) in smooth muscle [86, 88].

in smooth muscle $[86,88]$. Cyclic strain promotes Pyk2 and FAK phosphorylation at focal adhesion sites in cells. The integrin-mediated activation of tyrosine kinases in turn modulates the functional status of downstream molecules such as paxillin and Hic-5 that are related to remodeling of the actin architecture [14].

Contractile stimulation also induces the recruitment of structural proteins that participate in the linkage of actin filaments to $\beta$-integrin in adhesion sites, which may strengthen the connection of actin filaments with the membrane. The cytoskeletal protein vinculin is recruited to the ILK-associated complex at adhesion sites [55]. Vinculin binds to talin via its head domain and to actin filaments via its tail domain. Contractile activation induces vinculin phosphorylation, which promotes the binding of vinculin to talin and actin filaments and tension development $[29,51]$.

$\alpha$-Actinin is an actin cross-linking protein that also binds to integrin proteins. Stimulation with a contractile agonist induces rapidly the recruitment of $\alpha$ actinin to the integrin-associated complexes of canine tracheal smooth muscle cells/tissues [52]. In the tracheal tissues, the recruitment of $\alpha$-actinin is required for smooth muscle contraction but not for actin polymerization or myosin activation [52]. These observations demonstrate that disruption of the linkage of actin filaments to integrin-associated 
adhesions is sufficient to inhibit smooth muscle contraction [11, 14, 35] (Fig. 2).

\section{Small GTPases and PAK in smooth muscle}

Rho, Cdc42, and Rac are the members of the small GTPase Rho family. There is ample evidence that Cdc42 regulates actin polymerization in various cell types including smooth muscle cells [27, 28, 30, 89-92]. Activated Cdc42 binds to the GTP binding domain of $\mathrm{N}$-WASP, inducing a conformational change and activating $\mathrm{N}-\mathrm{WASP}$, and triggering the nucleation of actin polymerization and actin filament branching [11, 27, $28,73,74]$. In canine tracheal smooth muscle tissues, introduction of a dominant $\mathrm{Cdc} 42$ mutant depresses the activity of N-WASP concurrently with the decrease in actin polymerization and force development [11, 27, 28], suggesting that Cdc42-mediated actin assembly is essential for smooth muscle contraction.

Cdc42 and Rac are known to activate PAKs in mammalian cells [80, 93-96]. Although 6 isoforms have been found thus far, PAK1 is a major isoform in smooth muscle cells [80, 91-93, 95-98]. PAK has been shown to participate in the regulation of p38 MAP kinase in smooth muscle upon external activation [53, 93]. The activation of p38 MAP kinase may modulate the actin cytoskeleton and cell migration via heat shock protein 27 (HSP27) [14, 15, 53, 93]. In vitro biochemical studies have shown that unphosphorylated HSP25 (mouse and chicken homologs of HSP27) inhibits actin polymerization whereas phosphorylated HSP27 loses the ability to inhibit actin filament assembly [53, 94, 99, 100]. p38 MAP kinase may phosphorylate MAP kinase-activated protein (MAPKAP) kinase 2 (MK2), which subsequently catalyzes HSP27 phosphorylation and promotes actin polymerization and contraction [14, 53, 101] (Fig. 2).

PAK1 also regulates smooth muscle contraction by controlling the vimentin intermediate filament network $[80,91,92,94,95,97,102]$. Vimentin network undergoes phosphorylation at Ser-56 and spatial reorganization in smooth muscle cells/tissues in response to contractile stimulation, which is critical for smooth muscle force development [80, 95, 97, 102]. PAK1 deficiency reduces vimentin phosphorylation, reorientation of the vimentin network and smooth muscle contraction. Moreover, PAK1 is able to catalyze vimentin phosphorylation in vitro $[80,91,92,94,95,97,102,103]$. Thus, PAK1 regulates smooth muscle force development in part by modulating vimentin phosphorylation and reorientation of the vimentin network.

Rho activation promotes actin stress fiber formation in cultured smooth muscle cells [104, 105], and actin polymerization in smooth muscle tissues during contractile stimulation [30]. In canine tracheal smooth muscle, contractile stimulation activates RhoA, which induces the independent recruitment of paxillin-vinculin complexes and FAK to cell adhesomes. Activated FAK induces the phosphorylation of paxillin, which remains bound to activated vinculin. Paxillin phosphorylation also facilitates the formation of a complex containing paxillin and Crk II with DOCK180 and PIX GEFs. This complex induces the activation of $\mathrm{Cdc} 42$, which in turn promotes the activation of N-WASP, which interacts with the Arp $2 / 3$ complex to induce actin polymerization in the cortical region of the smooth muscle cell [30] (Fig. 2).

\section{Regulation of actin polymerization by histone deacetylase 8} Histone deacetylases (HDACs) are a family of enzymes that are originally identified as key regulators of histone deacetylation, nucleosome stability and gene transcription $[106,107]$. The HDAC family members have long been thought to regulate nucleosomal histone acetylation solely. HDACs typically induce histone deacetylation and repress gene transcription [108]. However, recent studies suggest that some HDACs are present in the cytoplasm of nonmuscle cells, which has been implicated in regulating cell migration and microtubule dynamics [109, 110].

HDAC8 is localized both in the cytoplasm and the nucleus of mouse and human airway smooth muscle cells. HDAC8 is required for the contraction of smooth muscle tissues [111] and cultured smooth muscle cells [112]. In addition, cortactin is an actin-regulatory protein that undergoes deacetylation during migration of $\mathrm{NIH}$ 3 T3 cells [110]. Contractile stimulation induces cortactin deacetylation in mouse and human smooth muscle tissues. Knockdown or pharmacological inhibition of HDAC8 attenuates cortactin deacetylation, actin polymerization and contraction without affecting myosin activation. Furthermore, expression of a charge-neutralizing cortactin mutant inhibits contraction and actin dynamics during agonist activation [111]. Taken together, these results suggest a novel paradigm for the regulation of actin dynamics in smooth muscle: Upon contractile activation, HDAC8 induces cortactin deacetylation, which in turn promotes actin polymerization and the contraction in airway smooth muscle (Fig. 2).

\section{Regulation by cofilin/ADF and vasodilator stimulated phosphoprotein (VASP)}

Cofilin/ADF are members of a family of "actin-dynamizing proteins," which are able to regulate the availability of actin monomers for actin filament assembly [11]. Cofilin binds to F-actin, severs actin filaments and provides more free barbed ends of actin filaments for nascent actin polymerization. Cofilin activity is regulated by its phosphorylation at Ser-3, which abolishes the ability of cofilin to bind to F-actin and thus inhibits its severing function $[11,45,113]$. 
In canine tracheal smooth muscle, contractile activation decreases cofilin phosphorylation at Ser-3, which is associated with force development [45]. Expression of an inactive phospho-cofilin mimetic (cofilin S3E) in the smooth muscle tissues inhibits endogenous ADF/cofilin dephosphorylation and actin polymerization. Expression of cofilin S3E in the tissues depresses tension development in response to $\mathrm{ACh}$, but it does not influence myosin light chain phosphorylation. These observations verify the role of cofilin in regulating the availability of actin monomers for actin polymerization in smooth muscle [11, 45]. In addition, cofilin phosphorylation at Ser-3 is regulated by protein phosphatase $2 \mathrm{~B}[11,45]$.

Members of the Ena/VASP protein family can promote actin polymerization by elongating actin filaments. The elongation mechanism involves VASP oligomerization and its binding to profilin and vinculin. In tracheal smooth muscle, treatment with ACh or forskolin (an adenylyl cyclase activator) increases VASP Ser-157 phosphorylation [44]. VASP undergoes phosphorylation at Ser-157 in a biphasic manner in aortic smooth muscle during stimulation with phenylephrine [35]. Treatment with ACh but not forskolin triggers the formation of VASP-VASP complexes as well as VASP-vinculin and VASP-profilin complexes at membrane sites. VASP-VASP complex formation and the interaction of VASP with vinculin and profilin are inhibited by an inactive vinculin mutant, but VASP phosphorylation and membrane localization are unaffected [44]. Gunst et al. conclude that VASP phosphorylation at Ser-157 mediates its localization at the membrane, but Ser-157 phosphorylation and membrane localization are not sufficient to activate its actin polymerization activity (as in the forskolin case). The interaction of VASP with activated vinculin at membrane sites is essential for VASP-mediated actin polymerization (Fig. 2) [44].

\section{Adherens junctions and smooth muscle contraction}

Adherens junctions are protein complexes that exist at cell-cell junctions in various cell types including epithelial cells, endothelial cells and muscle cells, which plays an essential role in intercellular connection and mechanotransduction [58, 114-116]. $\beta$-Catenin, a member of the armadillo family of proteins, is a key component of the cadherin-catenin complex in the plasma membrane [114]. $\beta$-Catenin is composed of an N-terminal head, an Arm (armadillo) domain and a C-terminal tail. The Arm domain of $\beta$-catenin binds to the cytoplasmic domain of cadherins; the extracellular domain of cadherins interacts with their counterparts of adjacent cells to form cell-cell contacts. The $\mathrm{N}$-terminus of $\beta$-catenin interacts with actin filaments via the linker proteins such as $\alpha$ catenin, vinculin and VASP $[115,117]$.

The cadherin-catenin complex is a mechanosensive and responsive structure [118]. The adherens junctions undergo reorganization in endothelial cells in response to tugging forces and thrombin treatment [118]. In keratinocytes, the engagement of the adherens junctions occurs upon chemical stimulation; the knockout of $\beta$-catenin disrupts the structural change [119]. The dynamic change of the adherens junctions may allow cells to adapt their mechanical property and intracellular signaling $[118,119]$.

$\beta$-cateninis a necessary component of the cellular process that regulates smooth muscle contraction $[58,120]$. However, $\beta$-catenin is not involved in the regulation of actin polymerization, myosin activation or contractile protein expression $[58,120]$. Contractile stimulation promotes the recruitment of $\beta$-catenin to $\mathrm{N}$ cadherin in human airway smooth muscle cells/tissues. This recruitment of $\beta$-catenin to $\mathrm{N}$-cadherin is critical for smooth muscle contraction. Disruption of the proteinprotein interaction by a $\beta$-catenin mutant attenuates smooth muscle force development [58]. More importantly, actin polymerization has a positive role in regulating the recruitment of $\beta$-catenin to $\mathrm{N}$-cadherin. Together, these findings reveal a novel role of adherens junctions in smooth muscle contraction: Contractile stimulation promotes actin polymerization, which may increase the coupling of $\beta$-catenin with $\mathrm{N}$-cadherin and facilitate intercellular mechanotransduction (Fig. 3).

\section{Role of actin-associated proteins in smooth muscle cell proliferation}

Cell adhesion, spreading and migration are recognized as important cellular processes that control cell proliferation. Disruption of these processes ultimately impairs the proliferation in various cell types including smooth muscle cells [20, 21, 61, 121-125]. Actin-regulatory proteins are known to regulate these cellular functions $[61,93,126]$. Thus, actin-associated proteins are capable of regulating cell proliferation by controlling cell adhesion, spreading and movement. In this section of the review, I will focus on the roles of Abl and PAK1 in growth factor-mediated signaling and cytokinesis.

\section{Regulation of smooth muscle cell proliferation by Abl tyrosine kinase}

$\mathrm{Abl}$ is activated in smooth muscle cells upon stimulation with platelet-derived growth factor (PDGF) and endothelin-1 [20, 21]. Endothilin-1 receptor is a member of G protein-coupled receptor (GPCR) family whereas PDGF receptor belongs to the family of tyrosine kinasecontaining receptors. Both GPCR and tyrosine kinase receptors play an important role in the regulation of smooth muscle cell functions [22, 127]. In rat vascular smooth muscle cells, activation of GPCR by agonists induces phosphorylation of Src at Tyr-416, which in turn triggers the activation of Abl [21, 47, 67]. Similarly, cellular 


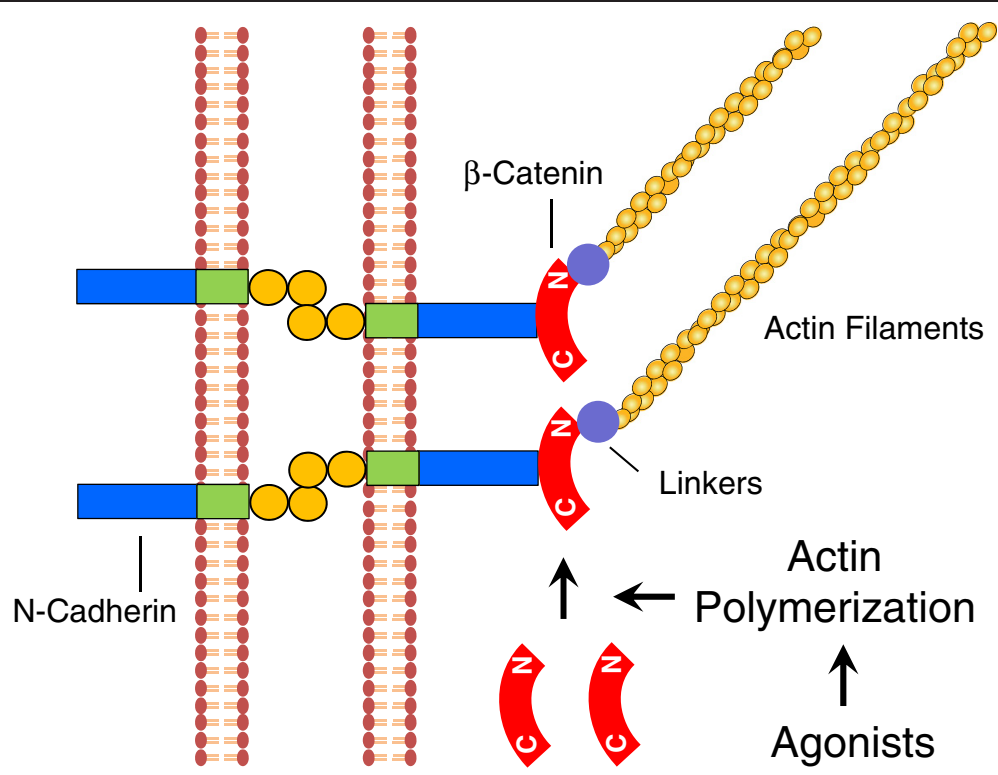

Fig. 3 Novel mechanism for regulation of adherens junctions in smooth muscle. In addition to myosin activation, contractile agonists induce actin polymerization, which promotes the recruitment of $\beta$-catenin to $\mathrm{N}$-cadherin. The increase in the protein-protein interaction may enhance the linkage of actin filaments to the adherens junctions, and promote the intercellular force transmission and smooth muscle contraction. C, C terminus; N, N terminus. Linkers, linker proteins such as a-catenin, vinculin and VASP

challenge with PDGF is able to activate Src, which subsequently mediates phosphorylation of Abl in mammalian cells $[21,128]$.

$\mathrm{Abl}$ is necessary for the proliferation in smooth muscle cells in response to activation with growth factors [20,21]. Upon the binding of ligands to growth factor receptors, Raf- 1 kinase is translocated to the plasma membrane, which subsequently activates Raf- 1 . Activated Raf- 1 phosphorylates MEK1/2 (MAPK kinase), which in turn phosphorylates and activates ERK1/2 and promotes cell proliferation $[22,23]$. In human airway smooth muscle cells, PDGF activation induces an increase in the association of Raf-1 with cytoskeletal actin. Inhibition of actin polymerization by Abl knockdown or latrunculin A attenuates the interaction of Raf- 1 with F-actin and Raf-1 redistribution during PDGF stimulation. Furthermore, Abl knockdown inhibits the PDGF-induced MEK and ERK1/2 phosphorylation and the proliferation in human airway smooth muscle cells (Fig. 4) [20, 21]. However, Abl does not affect AKT activation in smooth muscle cells upon growth factor stimulation [20, 21]. Abl regulation of ERK1/2 phosphorylation has also been reported in nonmuscle cells (e.g., fibroblasts); Abl appears to regulate SHP-2 tyrosine phosphatase, which subsequently modulates ERK1/2 activation in fibroblasts [129].

Abl also regulates smooth muscle cell proliferation by controlling cytokinesis, a critical step of cell division [125]. Abl is localized in the contractile ring of human airway smooth muscle cells. Knockdown or inhibition of $\mathrm{Abl}$ attenuates cytokinesis in smooth muscle cells [125].

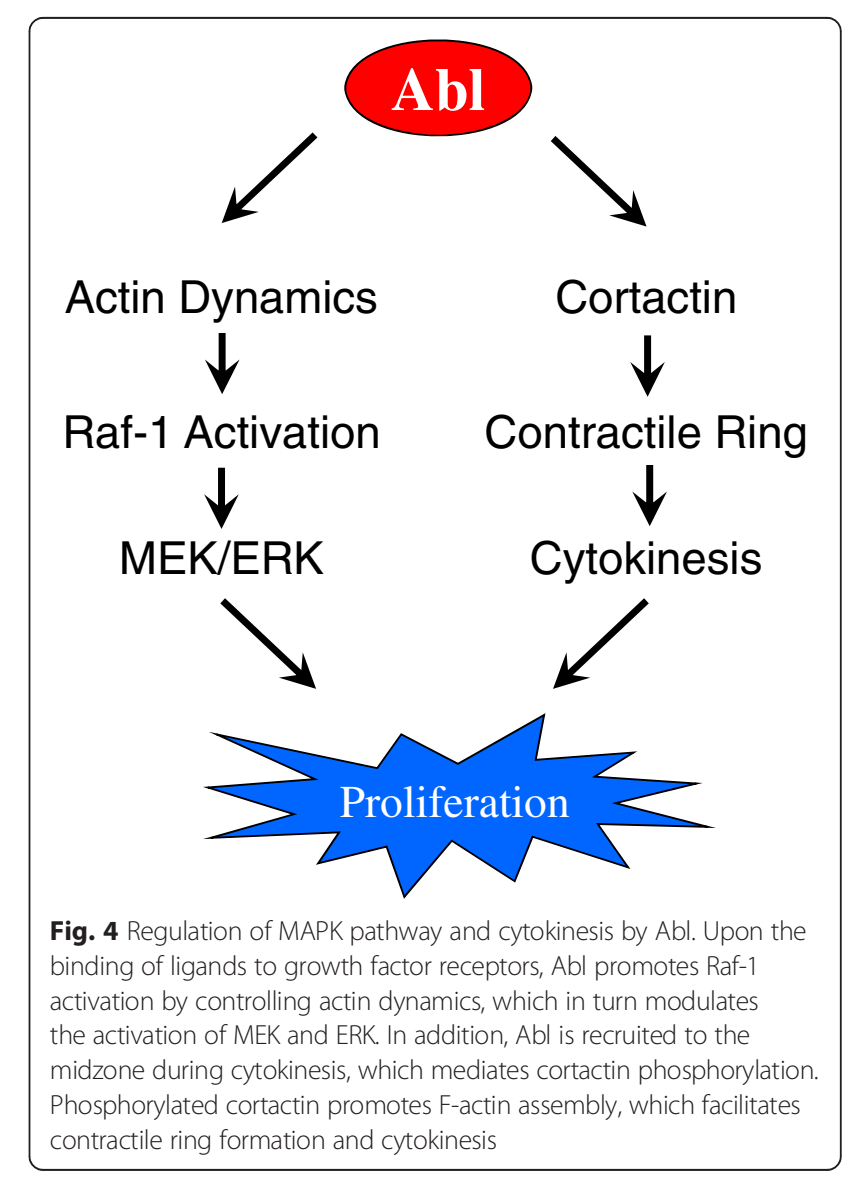


Cortactin is a tyrosine-phosphorylated protein that has been implicated in the regulation of actin filament assembly $[75,76]$. Phosphorylated cortactin is also found in the contractile ring. Abl knockdown or inhibition attenuates cortactin phosphorylation in the midzone and contractile ring formation. Furthermore, the expression of a nonphosphorylatable cortactin mutant diminishes cytokinesis. Thus, these results uncover a novel mechanism: Abl is recruited to the equator during cytokinesis, which mediates cortactin phosphorylation. Phosphorylated cortactin promotes actin filament assembly, which facilitates contractile ring formation and cytokinesis (Fig. 4) [125].

\section{Role of PAK1 in growth factor-mediated signaling}

PAK1 is phosphorylated and activated in rat aortic smooth muscle cells upon stimulation with growth factors and angiotensin II [130, 131]. Furthermore, PAK1 activity is necessary for rat aortic smooth muscle cell proliferation [24]. In addition, PAK1 is required for mitotic progress in nonmuscle cells [132].

PAK1 is likely to regulate smooth muscle cell proliferation by modulating ERK1/2 activation [133-135]. In response to cell adhesion to fibronectin, PAK mediates MEK1/2 phosphorylation at Ser-298, which subsequently promotes phosphorylation of Ser-218/Ser-222 and activates MEK1/2 [135]. Similarly, PAK1 is able to regulate ERK1/2 activation during migration of macrophage [133]. However, these studies have been performed in vascular smooth muscle cells or nonmuscle cells. Future studies are required to evaluate whether PAK1 has similar or distinctive role in airway smooth muscle cell proliferation.

\section{Role of cytoskeleton-regulatory proteins in AHR and airway remodeling}

Critical role of Abl in AHR and airway remodeling in vivo

Asthma is characterized by AHR and airway remodeling, which are largely due to increased airway smooth muscle contractility [1-5] and cell proliferation $[7,8]$. As described earlier, the function of Abl in smooth muscle contraction and cell proliferation in vitro has been documented. Until recently, the role of Abl tyrosine kinase in the pathogenesis of AHR and airway remodeling has been elusive. In a recent study [5], the expression of Abl is upregulated in airway smooth muscle tissues of an animal model of asthma and in asthmatic human airway smooth muscle cells. Conditional knockout of Abl in smooth muscle attenuates the methacholine-induced airway reactivity in animals sensitized and challenged with ovalbumin. Intranasal instillation with the Abl inhibitors imatinib and GNF-5 also inhibits airway resistance in the diseased animals. These results are supported by a previous study by others [64]. Furthermore, conditional knockout of Abl or treatment with the Abl inhibitors suppresses the agonist-induced airway smooth muscle hyperreactivity in vitro. The allergen-induced smooth muscle mass and cell proliferation are also reduced in the airways of Abl knockout mice or the inhibitortreated mice exposed to the allergen [5]. Taken in sum, these findings demonstrate a pivotal role of $\mathrm{Abl}$ in the allgern-induced AHR and airway remodeling in vivo.

In response to allergic sensitization and challenge, inflammatory cells enter into the lungs and cytokine/chemokine levels are increased in the bronchoalveolar space of asthmatic patients and animal models [4, 136, 137]. Because airway smooth muscle cells have ability to secrete cytokines in vitro [138], the effects of Abl knockout in smooth muscle on airway inflammation was also evaluated. Conditional knockout of Abl does not affect the increase in inflammatory cell numbers, IL-13 and CCL2 in animals sensitized and challenged by the allergen. On the contrary, treatment with imatinib and GNF-5 reduces the allergen-induced increase in inflammatory cell numbers, and levels of IL-13 and CCL2 [5]. The results suggest that global inhibition of $\mathrm{Abl}$ diminishes airway inflammation in chronic asthma, which is consistent with the findings that $\mathrm{Abl}$ may regulate migration and synthetic functions of immune cells in vitro [139-142].

There is a need to identify new biological target for the development of new therapy to treat asthma. As mentioned above, preclinical studies suggest that Abl has a critical role in the pathogenesis of AHR, airway remodeling and inflammation [5, 64]. In addition, clinical studies suggest that the Abl inhibitor imatinib is effective to lessen the clinical symptoms of patients with pulmonary arterial hypertension $[65,66]$, a disease that is also involved in abnormal smooth muscle cell contraction and proliferation. Thus, these findings support the concept that Abl may be a novel target for the development of new therapy to treat asthma.

\section{Role of PAK1 in AHR in vivo}

The potential role of PAK1 in the development of AHR was described in a recent study [6]. Tepper et al. demonstrate that inhibiting the activity of $\mathrm{p} 21$-activated protein kinase is an effective approach for reducing AHR in vivo. PAK1 knockout mice display significantly lower airway resistance in vivo, and the aerosol administration of a synthetic small molecule PAK inhibitor also reduces AHR in mice. Furthermore, isolated tracheal segments from $\mathrm{PAK}^{-1-}$ mice exhibit reduced contractile response in vitro, indicating that the decrease in airway reactivity observed in vivo in $\mathrm{PAK}^{-1-}$ mice results from decreased airway smooth muscle contraction [6].

However, they did not detect differences in the structure of the airways and lung parenchyma in PAK1 ${ }^{-/-}$ and wild type animals [6]. Decreased airway responsiveness does not appear to result from other factors that can alter airway responsiveness. These observations 
provide evidence that the reduction of PAK activity inhibits airway resistance in vivo and that this effect is caused by a reduction in the contractility of the airway smooth muscle. Furthermore, PAK inhibition is also able to attenuate the contraction in human bronchial tissues, which suggests that this approach could be effective in humans in vivo also.

\section{Conclusions and perspectives}

Exploring the functions and regulation of actin-associated proteins in smooth muscle is a new trend in smooth muscle physiology and asthma research. There is a wealth of evidence that actin polymerization is a key cellular process that controls smooth muscle contraction. Abl tyrosine kinase regulates actin cytoskeletal remodeling by controlling several downstream effectors including Abi1, cortactin and GMF- $\gamma$. Abl also has a role in regulating smooth muscle cell proliferation. Investigating potential roles of $\mathrm{Abl}$ in other smooth muscle functions is an interesting topic. There is emerging evidence that actin polymerization is modulated by protein deacetylation and that actin polymerization affects adherens junctions and cell-to-cell mechanotransduction. Understanding how protein acetylation/deacetylation and adherens junction assembly are regulated will be important directions in this research area. Abl and PAK1 are involved in the pathogenesis of asthma, suggesting that they are potential biotargets for the development of new treatment of asthma. Elegant technologies have been employed to unveil the roles of the integrin-associated complex and other actin-regulatory proteins in smooth muscle. However, there is not much information on whether these complex interactions are involved in asthma pathology. Filling this knowledge gap will enhance our understanding of asthma pathology.

\section{Abbreviations \\ Abi1: Abl interactor 1; Abl: Abelson tyrosine kinase; ACh: Acetylcholine; ADF: Actin-depolymerization factor; AHR: Airway hyperresponsiveness; CAS: Crk-associated substrates; ERK1/2: Extracellular signal-regulated kinase1/2; FAK: Focal adhesion kinase; GMF-ү: Glia maturation factor- - ; GPCR: G protein- coupled receptor; HDACs: Histone deacetylases; HSP: Heat shock protein; IL: Interleukin; ILK: Integrin-linked kinase; MAPK: Mitogen-activated protein kinase; MK2: MAP kinase-activated protein (MAPKAP) kinase 2; N-WASP: Neuronal Wiskott-Aldrich Syndrome Protein; PAK: p21-activated kinase; PDGF: Platelet- derived growth factor; Pfn-1: profilin-1; VASP: Vasodilator stimulated phosphoprotein.}

\section{Competing interests}

The author declares that he has no competing interests.

\section{Author's contribution}

The author wrote the manuscript.

\section{Acknowledgments}

This work was supported by NHLBI Grants HL-110951 and HL-113208 from the National Institutes of Health (to Dale D. Tang).

Received: 4 June 2015 Accepted: 22 October 2015

Published online: 30 October 2015

\section{References}

1. Amrani Y, Tliba O, Deshpande DA, Walseth TF, Kannan MS, Panettieri Jr RA. Bronchial hyperresponsiveness: insights into new signaling molecules. Curr Opin Pharmacol. 2004;4:230-4.

2. Ma XF, Cheng ZQ, Kong H, Wang Y, Unruh H, Stephens NL, et al. Changes in biophysical and biochemical properties of single bronchial smooth muscle cells from asthmatic subjects. Am J Physiol Lung Cell Mol Physiol. 2002;283:L1181-9.

3. Bjorck T, Gustafsson LE, Dahlen SE. Isolated bronchi from asthmatics are hyperresponsive to adenosine, which apparently acts indirectly by liberation of leukotrienes and histamine. Am Rev Respir Dis. 1992;145:1087-91.

4. Guedes AG, Paulin J, Rivero-Nava L, Kita H, Lund FE, Kannan MS. CD38deficient mice have reduced airway hyperresponsiveness following IL-13 challenge. Am J Physiol Lung Cell Mol Physiol. 2006;291:L1286-93.

5. Cleary RA, Wang R, Wang T, Tang DD. Role of Abl in airway hyperresponsiveness and airway remodeling. Respir Res. 2013;14:105.

6. Hoover WC, Zhang W, Xue Z, Gao H, Chernoff J, Clapp DW, et al. Inhibition of p21 activated kinase (PAK) reduces airway responsiveness in vivo and in vitro in murine and human airways. PLoS One. 2012;7:e42601.

7. Ammit AJ, Panettieri Jr RA. Airway smooth muscle cell hyperplasia: a therapeutic target in airway remodeling in asthma? Prog Cell Cycle Res. 2003;5:49-57.

8. Dekkers BG, Bos IS, Gosens R, Halayko AJ, Zaagsma J, Meurs H. The integrinblocking peptide RGDS inhibits airway smooth muscle remodeling in a guinea pig model of allergic asthma. Am J Respir Crit Care Med. 2010;181:556-65

9. Kamm KE, Stull JT. Regulation of smooth muscle contractile elements by second messengers. Annu Rev Physiol. 1989;51:299-313.

10. Somlyo AV, Khromov AS, Webb MR, Ferenczi MA, Trentham DR, He ZH, et al. Smooth muscle myosin: regulation and properties. Philos Trans R Soc Lond B Biol Sci. 2004;359:1921-30.

11. Gunst SJ, Zhang W. Actin cytoskeletal dynamics in smooth muscle: a new paradigm for the regulation of smooth muscle contraction. Am J Physiol Cell Physiol. 2008;295:C576-87.

12. Kim HR, Gallant C, Leavis PC, Gunst SJ, Morgan KG. Cytoskeletal remodeling in differentiated vascular smooth muscle is actin isoform dependent and stimulus dependent. Am J Physiol Cell Physiol. 2008;295:C768-78.

13. Rembold CM, Tejani AD, Ripley ML, Han S. Paxillin phosphorylation, actin polymerization, noise temperature, and the sustained phase of swine carotid artery contraction. Am J Physiol Cell Physiol. 2007;293:C993-1002

14. Tang DD, Anfinogenova Y. Physiologic properties and regulation of the actin cytoskeleton in vascular smooth muscle. J Cardiovasc Pharmacol Ther. 2008;13:130-40.

15. Tang DD. p130 Crk-Associated Substrate (CAS) in Vascular Smooth Muscle. J Cardiovasc Pharmacol Ther. 2009;14:89-98.

16. Wang T, Cleary RA, Wang R, Tang DD. Glia maturation factor-gamma phosphorylation at Tyr-104 regulates actin dynamics and contraction in human airway smooth muscle. Am J Respir Cell Mol Biol. 2014;51:652-9.

17. Wang T, Cleary RA, Wang R, Tang DD. Role of the adapter protein Abi1 in actin-associated signaling and smooth muscle contraction. J Biol Chem. 2013:288:20713-22.

18. Wang R, Cleary RA, Wang T, Li J, Tang DD. The association of cortactin with profilin-1 is critical for smooth muscle contraction. J Biol Chem. 2014;289:14157-69.

19. Chen C, Krishnan R, Zhou E, Ramachandran A, Tambe D, Rajendran K, et al. Fluidization and resolidification of the human bladder smooth muscle cell in response to transient stretch. PLoS One. 2010;5:e12035.

20. Wang R, Mercaitis OP, Jia L, Panettieri RA, Tang DD. Raf-1, actin dynamics and $\mathrm{Abl}$ in human airway smooth muscle cells. Am J Respir Cell Mol Biol 2013:48:172-8

21. Jia L, Wang R, Tang DD. Abl regulates smooth muscle cell proliferation by modulating actin dynamics and ERK1/2 activation. Am J Physiol Cell Physiol. 2012;302:C1026-34.

22. Widmann C, Gibson S, Jarpe MB, Johnson GL. Mitogen-activated protein kinase: conservation of a three-kinase module from yeast to human. Physiol Rev. 1999;79:143-80.

23. Chang L, Karin M. Mammalian MAP kinase signalling cascades. Nature. 2001;410:37-40.

24. Hinoki A, Kimura K, Higuchi S, Eguchi K, Takaguri A, Ishimaru K, et al. p21activated kinase 1 participates in vascular remodeling in vitro and in vivo. Hypertension. 2010;55:161-5. 
25. Gunst SJ, Tang DD. The contractile apparatus and mechanical properties of airway smooth muscle. Eur Respir J. 2000;15:600-16.

26. Small JV, Gimona M. The cytoskeleton of the vertebrate smooth muscle cell. Acta Physiol Scand. 1998;164:341-8.

27. Tang DD, Zhang W, Gunst SJ. The adapter protein Crkll regulates neuronal Wiskott-Aldrich syndrome protein, actin polymerization, and tension development during contractile stimulation of smooth muscle. J Biol Chem. 2005;280:23380-9.

28. Tang DD, Gunst SJ. The small GTPase Cdc42 regulates actin polymerization and tension development during contractile stimulation of smooth muscle. J Biol Chem. 2004;279:51722-8.

29. Huang $Y L$, Zhang WW, Gunst SJ. Activation of vinculin induced by cholinergic stimulation regulates contraction of tracheal smooth muscle tissue. J Biol Chem. 2011;286:3630-44.

30. Zhang W, Huang Y, Gunst SJ. The small GTPase RhoA regulates the contraction of smooth muscle tissues by catalyzing the assembly of cytoskeletal signaling complexes at membrane adhesion sites. J Biol Chem. 2012;287:33996-4008.

31. Chen X, Pavlish K, Zhang HY, Benoit JN. Effects of chronic portal hypertension on agonist-induced actin polymerization in small mesenteric arteries. Am J Physiol Heart Circ Physiol. 2006;290:H1915-21.

32. Tang DD, Tan J. Downregulation of profilin with antisense oligodeoxynucleotides inhibits force development during stimulation of smooth muscle. Am J Physiol Heart Circ Physiol. 2003;285:H1528-36.

33. Hirshman CA, Zhu D, Pertel T, Panettieri RA, Emala CW. Isoproterenol induces actin depolymerization in human airway smooth muscle cells via activation of an Src kinase and GS. Am J Physiol Lung Cell Mol Physiol. 2005;288:L924-31.

34. Chen S, Wang R, Li QF, Tang DD. Abl knockout differentially affects p130 Crk-associated substrate, vinculin, and paxillin in blood vessels of mice. Am J Physiol Heart Circ Physiol. 2009;297:H533-9.

35. Kim HR, Graceffa P, Ferron F, Gallant C, Boczkowska M, Dominguez R, et al. Actin polymerization in differentiated vascular smooth muscle cells requires vasodilator-stimulated phosphoprotein. Am J Physiol Cell Physiol. 2010;298:C559-71.

36. Hirshman CA, Zhu D, Panettieri RA, Emala CW. Actin depolymerization via the beta-adrenoceptor in airway smooth muscle cells: a novel PKAindependent pathway. Am J Physiol Cell Physiol. 2001;281:C1468-76.

37. Hirshman CA, Emala CW. Actin reorganization in airway smooth muscle cells involves Gq and Gi-2 activation of Rho. Am J Physiol. 1999;277:L653-61.

38. Barany M, Barron JT, Gu L, Barany K. Exchange of the actin-bound nucleotide in intact arterial smooth muscle. J Biol Chem. 2001;276:48398-403.

39. Tang DD, Tan J. Role of Crk-associated substrate in the regulation of vascular smooth muscle contraction. Hypertension. 2003:42:858-63.

40. Adler KB, Krill J, Alberghini TV, Evans JN. Effect of cytochalasin D on smooth muscle contraction. Cell Motility. 1983;3:545-51.

41. Obara K, Yabu H. Effect of cytochalasin B on intestinal smooth muscle cells Eur J Pharmacol. 1994;255:139-47.

42. Coue M, Brenner SL, Spector I, Korn ED. Inhibition of actin polymerization by latrunculin A. FEBS Lett. 1987;213:316-8.

43. Cooper JA. Effects of cytochalasin and phalloidin on actin. J Cell Biol. 1987;105:1473-8.

44. Wu Y, Gunst SJ. Vasodilator-stimulated Phosphoprotein (VASP) Regulates Actin Polymerization and Contraction in Airway Smooth Muscle by a Vinculin-dependent Mechanism. J Biol Chem. 2015;290:11403-16

45. Zhao R, Du L, Huang Y, Wu Y, Gunst SJ. Actin depolymerization factor/ cofilin activation regulates actin polymerization and tension development in canine tracheal smooth muscle. J Biol Chem. 2008;283:36522-31.

46. Wu Y, Huang $Y$, Herring BP, Gunst SJ. Integrin-linked kinase regulates smooth muscle differentiation marker gene expression in airway tissue. Am J Physiol Lung Cell Mol Physiol. 2008;295:L988-97.

47. Jia L, Tang DD. Abl activation regulates the dissociation of CAS from cytoskeletal vimentin by modulating CAS phosphorylation in smooth muscle. Am J Physiol Cell Physiol. 2010;299:C630-7.

48. Anfinogenova Y, Wang R, Li QF, Spinelli AM, Tang DD. Abl silencing inhibits CAS-Mediated process and constriction in resistance arteries. Circ Res. 2007;101:420-8

49. Gunst SJ, Tang DD, Opazo SA. Cytoskeletal remodeling of the airway smooth muscle cell: a mechanism for adaptation to mechanical forces in the lung. Respir Physiol Neurobiol. 2003;137:151-68.
50. Burridge K, Chrzanowska-Wodnicka M. Focal adhesions, contractility, and signaling. Annu Rev Cell Dev Biol. 1996;12:463-518.

51. Huang Y, Day RN, Gunst SJ. Vinculin phosphorylation at Tyr 1065 regulates vinculin conformation and tension development in airway smooth muscle tissues. J Biol Chem. 2014;289:3677-88.

52. Zhang W, Gunst SJ. Dynamic association between alpha-actinin and beta-integrin regulates contraction of canine tracheal smooth muscle. J Physiol. 2006:572:659-76.

53. Gerthoffer WT, Gunst SJ. Invited review: focal adhesion and small heat shock proteins in the regulation of actin remodeling and contractility in smooth muscle. J Appl Physiol. 2001;91:963-72.

54. Zhang W, Wu Y, Du L, Tang DD, Gunst SJ. Activation of the Arp2/3 complex by N-WASp is required for actin polymerization and contraction in smooth muscle. Am J Physiol Cell Physiol. 2005;288:C1145-60.

55. Zhang W, Wu Y, Wu C, Gunst SJ. Integrin-linked kinase regulates N-WASpmediated actin polymerization and tension development in tracheal smooth muscle. J Biol Chem. 2007;282:34568-80.

56. Murphy RA, Rembold CM. The latch-bridge hypothesis of smooth muscle contraction. Can J Physiol Pharmacol. 2005;83:857-64.

57. Meeks MK, Ripley ML, Jin Z, Rembold CM. Heat shock protein 20-mediated force suppression in forskolin-relaxed swine carotid artery. Am J Physiol Cell Physiol. 2005;288:C633-9.

58. Wang T, Wang R, Cleary RA, Gannon OJ, Tang DD. Recruitment of betaCatenin to $\mathrm{N}$-Cadherin is necessary for smooth muscle contraction. J Biol Chem. 2015;290:8913-24.

59. Hu H, Bliss JM, Wang Y, Colicelli J. RIN1 is an ABL tyrosine kinase activator and a regulator of epithelial-cell adhesion and migration. Curr Biol. 2005;15:815-23.

60. Wang JY. Controlling Abl: auto-inhibition and co-inhibition? Nat Cell Biol. 2004;6:3-7.

61. Cleary RA, Wang R, Waqar O, Singer HA, Tang DD. Role of c-Abl tyrosine kinase in smooth muscle cell migration. Am J Physiol Cell Physiol. 2014;306:C753-61.

62. Daniels CE, Wilkes MC, Edens M, Kottom TJ, Murphy SJ, Limper AH, et al. Imatinib mesylate inhibits the profibrogenic activity of TGF-beta and prevents bleomycin-mediated lung fibrosis. J Clin Invest. 2004;114:1308-16.

63. Zhang J, Adrian FJ, Jahnke W, Cowan-Jacob SW, Li AG, lacob RE, et al. Targeting Bcr-Abl by combining allosteric with ATP-binding-site inhibitors. Nature. 2010;463:501-6.

64. Berlin AA, Lukacs NW. Treatment of cockroach allergen asthma model with imatinib attenuates airway responses. Am J Respir Crit Care Med. 2005;171:35-9.

65. Ghofrani HA, Seeger W, Grimminger F. Imatinib for the treatment of pulmonary arterial hypertension. N Engl J Med. 2005;353:1412-3.

66. ten Freyhaus H, Dumitrescu D, Berghausen E, Vantler M, Caglayan E, Rosenkranz S. Imatinib mesylate for the treatment of pulmonary arterial hypertension. Expert Opin Investig Drugs. 2012;21:119-34

67. Ogden K, Thompson JM, Hickner Z, Huang T, Tang DD, Watts SW. A new signaling paradigm for serotonin: use of Crk-associated substrate in arterial contraction. Am J Physiol Heart Circ Physiol. 2006;291:H2857-63.

68. Plattner R, Kadlec L, DeMali KA, Kazlauskas A, Pendergast AM. c-Abl is activated by growth factors and Src family kinases and has a role in the cellular response to PDGF. Genes Dev. 1999;13:2400-11.

69. Khusial RP, Vadla B, Krishnan H, Ramlall TF, Shen Y, Ichikawa H, et al. Src activates Abl to augment Robo1 expression in order to promote tumor cell migration. Oncotarget. 2010;1:198-209.

70. Innocenti M, Gerboth S, Rottner K, Lai FP, Hertzog M, Stradal TE, et al. Abi1 regulates the activity of N-WASP and WAVE in distinct actin-based processes. Nat Cell Biol. 2005;7:969-76.

71. Ryu JR, Echarri A, Li R, Pendergast AM. Regulation of cell-cell adhesion by Abi/Diaphanous complexes. Mol Cell Biol. 2009;29:1735-48.

72. Stradal T, Courtney KD, Rottner K, Hahne P, Small JV, Pendergast AM. The $\mathrm{Abl}$ interactor proteins localize to sites of actin polymerization at the tips of lamellipodia and filopodia. Curr Biol. 2001;11:891-5.

73. Higgs HN, Pollard TD. Activation by Cdc42 and PIP(2) of Wiskott-Aldrich syndrome protein (WASp) stimulates actin nucleation by Arp2/3 complex. J Cell Biol. 2000;150:1311-20.

74. Pollard TD. Regulation of actin filament assembly by Arp2/3 complex and formins. Annu Rev Biophys Biomol Struct. 2007;36:451-77.

75. Ammer AG, Weed SA. Cortactin branches out: roles in regulating protrusive actin dynamics. Cell Motil Cytoskeleton. 2008;65:687-707. 
76. Cosen-Binker LI, Kapus A. Cortactin: the gray eminence of the cytoskeleton. Physiology(Bethesda). 2006;21:352-61.

77. Gandhi M, Smith BA, Bovellan M, Paavilainen V, Ugherty-Clarke K, Gelles J, et al. GMF is a cofilin homolog that binds Arp2/3 complex to stimulate filament debranching and inhibit actin nucleation. Curr Biol. 2010;20:861-7.

78. Ydenberg CA, Padrick SB, Sweeney MO, Gandhi M, Sokolova O, Goode BL. GMF severs actin-Arp2/3 complex branch junctions by a cofilin-like mechanism. Curr Biol. 2013;23:1037-45.

79. Galbraith CG, Yamada KM, Sheetz MP. The relationship between force and focal complex development. J Cell Biol. 2002;159:695-705.

80. Wang R, Li QF, Anfinogenova Y, Tang DD. Dissociation of Crk-associated substrate from the vimentin network is regulated by p21-activated kinase on ACh activation of airway smooth muscle. Am J Physiol Lung Cell Mol Physiol. 2007;292:L240-8.

81. Gunst SJ, Wu MF. Effects of muscle length on intracellular Ca2+ during isometric contraction of tracheal smooth muscle. Adv Exp Med Biol. 1991;304:435-43.

82. Tang DD, Wu MF, Opazo Saez AM, Gunst SJ. The focal adhesion protein paxillin regulates contraction in canine tracheal smooth muscle. J Physiol. 2002;542:501-13.

83. Tang DD, Turner CE, Gunst SJ. Expression of non-phosphorylatable paxillin mutants in canine tracheal smooth muscle inhibits tension development. J Physiol. 2003;553:21-35.

84. Turner CE, Pietras KM, Taylor DS, Molloy CJ. Angiotensin II stimulation of rapid paxillin tyrosine phosphorylation correlates with the formation of focal adhesions in rat aortic smooth muscle cells. J Cell Sci. 1995;108:333-42.

85. Sul D, Baron CB, Broome R, Coburn RF. Smooth muscle length-dependent $\mathrm{PI}(4,5) \mathrm{P} 2$ synthesis and paxillin tyrosine phosphorylation. Am J Physiol Cell Physiol. 2001;281:C300-10.

86. Tang D, Mehta D, Gunst SJ. Mechanosensitive tyrosine phosphorylation of paxillin and focal adhesion kinase in tracheal smooth muscle. Am J Physiol. 1999;276:C250-8.

87. Tang DD, Gunst SJ. Depletion of focal adhesion kinase by antisense depresses contractile activation of smooth muscle. Am J Physiol Cel Physiol. 2001;280:C874-83.

88. Tang DD, Gunst SJ. Selected contribution: roles of focal adhesion kinase and paxillin in the mechanosensitive regulation of myosin phosphorylation in smooth muscle. J Appl Physiol. 2001;91:1452-9.

89. Cau J, Hall A. Cdc42 controls the polarity of the actin and microtubule cytoskeletons through two distinct signal transduction pathways. J Cell Sci. 2005;118:2579-87.

90. Zigmond SH, Joyce M, Yang C, Brown K, Huang M, Pring M. Mechanism of Cdc42-induced actin polymerization in neutrophil extracts. J Cell Biol. 1998;142:1001-12.

91. Li QF, Tang DD. Role of p47(phox) in regulating Cdc42GAP, vimentin, and contraction in smooth muscle cells. Am J Physiol Cell Physiol. 2009;297:C1424-33.

92. Li QF, Spinelli AM, Tang DD. Cdc42GAP, reactive oxygen species, and the vimentin network. Am J Physiol Cell Physiol. 2009;297:C299-309.

93. Dechert MA, Holder JM, Gerthoffer WT. p21-activated kinase 1 participates in tracheal smooth muscle cell migration by signaling to p38 Mapk. Am J Physiol Cell Physiol. 2001;281:C123-32.

94. Tang DD. Invited review: intermediate filaments in smooth muscle. Am J Physiol Cell Physiol. 2008;294:C869-78.

95. Li QF, Spinelli AM, Wang R, Anfinogenova Y, Singer HA, Tang DD. Critical role of vimentin phosphorylation at Ser-56 by p21-activated kinase in vimentin cytoskeleton signaling. J Biol Chem. 2006;281:34716-24.

96. Jaffer ZM, Chernoff J. p21-activated kinases: three more join the Pak. Int J BiochemCell Biol. 2002;34:713-7.

97. Tang DD, Bai Y, Gunst SJ. Silencing of p21-activated kinase attenuates vimentin phosphorylation on Ser-56 and reorientation of the vimentin network during stimulation of smooth muscle cells by 5-hydroxytryptamine. Biochem J. 2005;388:773-83.

98. Webb BA, Eves R, Crawley SW, Zhou S, Cote GP, Mak AS. PAK1 induces podosome formation in A7r5 vascular smooth muscle cells in a PAKinteracting exchange factor-dependent manner. Am J Physiol Cell Physiol. 2005;289:C898-907.

99. Benndorf R, Hayess K, Ryazantsev S, Wieske M, Behlke J, Lutsch G. Phosphorylation and supramolecular organization of murine small heat shock protein HSP25 abolish its actin polymerization- inhibiting activity. J Biol Chem. 1994;269:20780-4.
100. Miron T, Vancompernolle K, Vanderkerckhove J, Wilchek M, Geiger B. A $25-\mathrm{kD}$ inhibitor of actin polymerization is a low molecular mass heat shock protein. J Cell Biol. 1991;114:255-61.

101. Gerthoffer WT. Actin cytoskeletal dynamics in smooth muscle contraction. Can J Physiol Pharmacol. 2005;83:851-6.

102. Wang R, Li Q, Tang DD. Role of vimentin in smooth muscle force development. Am J Physiol Cell Physiol. 2006;291:C483-9.

103. Henrion D, Terzi F, Matrougui K, Duriez M, Boulanger CM, Colucci-Guyon E, et al. Impaired flow-induced dilation in mesenteric resistance arteries from mice lacking vimentin. J Clin Invest. 1997;100:2909-14.

104. Togashi H, Emala CW, Hall IP, Hirshman CA. Carbachol-induced actin reorganization involves $\mathrm{Gi}$ activation of Rho in human airway smooth muscle cells. Am J Physiol. 1998;274:L803-9.

105. Hirshman CA, Togashi H, Shao D, Emala CW. Galphai-2 is required for carbachol-induced stress fiber formation in human airway smooth muscle cells. Am J Physiol. 1998;275:L911-6.

106. Grunstein M. Histone acetylation in chromatin structure and transcription. Nature. 1997;389:349-52.

107. Megee PC, Morgan BA, Mittman BA, Smith MM. Genetic analysis of histone H4: essential role of lysines subject to reversible acetylation. Science. 1990;247:841-5

108. de Ruijter AJ, van Gennip AH, Caron HN, Kemp S, van Kuilenburg AB. Histone deacetylases (HDACs): characterization of the classical HDAC family. Biochem J. 2003:370:737-49.

109. Haggarty SJ, Koeller KM, Wong JC, Grozinger CM, Schreiber SL. Domainselective small-molecule inhibitor of histone deacetylase 6 (HDAC6)mediated tubulin deacetylation. Proc Natl Acad Sci U S A. 2003;100:4389-94.

110. Zhang X, Yuan Z, Zhang Y, Yong S, Salas-Burgos A, Koomen J, et al. HDAC6 modulates cell motility by altering the acetylation level of cortactin. Mol Cell. 2007;27:197-213.

111. Li J, Chen S, Cleary RA, Wang R, Gannon OJ, Seto E, et al. Histone deacetylase 8 regulates cortactin deacetylation and contraction in smooth muscle tissues. Am J Physiol Cell Physiol. 2014;307:C288-95.

112. Waltregny D, Glenisson W, Tran SL, North BJ, Verdin E, Colige A, et al. Histone deacetylase HDAC8 associates with smooth muscle alpha-actin and is essential for smooth muscle cell contractility. Faseb J. 2005;19:966-8.

113. Bamburg JR. Proteins of the ADF/cofilin family: essential regulators of actin dynamics. Annu Rev Cell Dev Biol. 1999;15:185-230.

114. Pokutta S, Weis WI. Structure and mechanism of cadherins and catenins in cell-cell contacts. Annu Rev Cell Dev Biol. 2007;23:237-61.

115. Jamora C, Fuchs E. Intercellular adhesion, signalling and the cytoskeleton. Nat Cell Biol. 2002;4:E101-8.

116. Belkin AM, Klimanskaya IV, Lukashev ME, Lilley K, Critchley DR, Koteliansky VE. A novel phosphoglucomutase-related protein is concentrated in adherens junctions of muscle and nonmuscle cells. J Cell Sci. 1994;107(Pt 1):159-73.

117. Castano J, Raurell I, Piedra JA, Miravet S, Dunach M, de HA G. Beta-catenin $\mathrm{N}$ - and C-terminal tails modulate the coordinated binding of adherens junction proteins to beta-catenin. J Biol Chem. 2002;277:31541-50.

118. Liu Z, Tan JL, Cohen DM, Yang MT, Sniadecki NJ, Ruiz SA, et al. Mechanical tugging force regulates the size of cell-cell junctions. Proc Natl Acad Sci U S A. 2010;107:9944-9.

119. Ray S, Foote HP, Lechler T. beta-Catenin protects the epidermis from mechanical stresses. J Cell Biol. 2013;202:45-52.

120. Jansen SR, Van Ziel AM, Baarsma HA, Gosens R. \{beta\}-Catenin regulates airway smooth muscle contraction. Am J Physiol Lung Cell Mol Physiol. 2010;299:L204-14.

121. Pinon P, Wehrle-Haller B. Integrins: versatile receptors controlling melanocyte adhesion, migration and proliferation. Pigment Cell Melanoma Res. 2011;24:282-94.

122. Ding ZJ, Lambrechts A, Parepally M, Roy P. Silencing profilin-1 inhibits endothelial cell proliferation, migration and cord morphogenesis. J Cell Sci. 2006;119:4127-37.

123. Woodring PJ, Meisenhelder J, Johnson SA, Zhou GL, Field J, Shah K, et al c-Abl phosphorylates Dok1 to promote filopodia during cell spreading J Cell Biol. 2004;165:493-503.

124. Gerthoffer WT. Migration of airway smooth muscle cells. Proc Am Thorac Soc. 2008:5:97-105.

125. Chen S, Tang DD. c-Abl tyrosine kinase regulates cytokinesis of human airway smooth muscle cells. Am J Respir Cell Mol Biol. 2014;50:1076-83.

126. Panetti TS. Tyrosine phosphorylation of paxillin, FAK, and p130CAS: effects on cell spreading and migration. Front Biosci. 2002;7:d143-50. 
127. Goncharova EA, Goncharov DA, Zhao H, Penn RB, Krymskaya VP, Panettieri Jr RA. beta2-adrenergic receptor agonists modulate human airway smooth muscle cell migration via vasodilator-stimulated phosphoprotein. Am J Respir Cell Mol Biol. 2012:46:48-54.

128. Hantschel O, Superti-Furga G. Regulation of the c-Abl and Bcr-Abl tyrosine kinases. Nat Rev Mol Cell Biol. 2004;5:33-44.

129. Mitra S, Beach C, Feng GS, Plattner R. SHP-2 is a novel target of Abl kinases during cell proliferation. J Cell Sci. 2008;121:3335-46.

130. Woolfolk EA, Eguchi S, Ohtsu H, Nakashima H, Ueno H, Gerthoffer WT, et al. Angiotensin I-induced activation of p21-activated kinase 1 requires $\mathrm{Ca} 2+$ and protein kinase C\{delta\} in vascular smooth muscle cells. Am J Physiol Cell Physiol. 2005;289:C1286-94.

131. Beier I, Dusing R, Vetter $H$, Schmitz U. Epidermal growth factor stimulates Rac1 and p21-activated kinase in vascular smooth muscle cells. Atherosclerosis. 2008;196:92-7.

132. Maroto B, Ye MB, von Lohneysen K, Schnelzer A, Knaus UG. P21-activated kinase is required for mitotic progression and regulates Plk1. Oncogene. 2008;27:4900-8.

133. Smith SD, Jaffer ZM, Chernoff J, Ridley AJ. PAK1-mediated activation of ERK1/2 regulates lamellipodial dynamics. J Cell Sci. 2008;121:3729-36.

134. Eblen ST, Slack JK, Weber MJ, Catling AD. Rac-PAK signaling stimulates extracellular signal-regulated kinase (ERK) activation by regulating formation of MEK1-ERK complexes. Mol Cell Biol. 2002;22:6023-33.

135. Slack-Davis JK, Eblen ST, Zecevic M, Boerner SA, Tarcsafalvi A, Diaz HB, et al. PAK1 phosphorylation of MEK1 regulates fibronectin-stimulated MAPK activation. J Cell Biol. 2003;162:281-91.

136. Wills-Karp M. Interleukin-13 in asthma pathogenesis. Immunol Rev. 2004;202:175-90

137. Zimmermann N, Hershey GK, Foster PS, Rothenberg ME. Chemokines in asthma: cooperative interaction between chemokines and IL-13. J Allergy Clin Immunol. 2003;111:227-42

138. Howarth PH, Knox AJ, Amrani Y, Tliba O, Panettieri Jr RA, Johnson M. Synthetic responses in airway smooth muscle. J Allergy Clin Immunol. 2004;114:\$32-50.

139. Brightbill $H$, Schlissel MS. The effects of c-Abl mutation on developing B cell differentiation and survival. Int Immunol. 2009;21:575-85.

140. Huang Y, Comiskey EO, Dupree RS, Li S, Koleske AJ, Burkhardt JK. The c-Abl tyrosine kinase regulates actin remodeling at the immune synapse. Blood. 2008;112:111-9.

141. Silberman I, Sionov RV, Zuckerman V, Haupt S, Goldberg Z, Strasser A, et al T cell survival and function requires the c-Abl tyrosine kinase. Cell Cycle. 2008;7:3847-57.

142. Baruzzi A, Berton G. The tyrosine kinase Abl is a component of macrophage podosomes and is required for podosome formation and function. Eur J Immunol. 2012;42:2720-6.

\section{Submit your next manuscript to BioMed Central and take full advantage of:}

- Convenient online submission

- Thorough peer review

- No space constraints or color figure charges

- Immediate publication on acceptance

- Inclusion in PubMed, CAS, Scopus and Google Scholar

- Research which is freely available for redistribution 